Original Article

\title{
Efficiency of Levamisole in Improving the Immune Response of Catfish (Clarias Gariepenus) to Aeromonas Hydrophila Vaccine: Clinico- Pathological Studies
}

\author{
Salah Aly ${ }^{1}$; Osama Abd-Allah'; Amina Mahmoud $^{3}$ and Hala Gafer ${ }^{3}$ \\ ${ }^{1}$ The WorldFish Center, Abbassa, Sharkia; ${ }^{2}$ Department of Clinical Pathology, Faculty of Veterinary Medline, Suez \\ Canal University and ${ }^{3}$ Animal Health Research Institute, Dokki, Giza, Egypt.
}

\begin{abstract}
The effect of Levamisole on the immune response of 200 catfish (Clarias gariepenus) was evaluated. Fish were divided into 4 equal groups, reared in a glass aquaria and fed on a basal diet. The $1^{\text {st }}$ group served as a control. Fish of the $2^{\text {nd }}$ group was incorporating Levamisole $(150 \mathrm{mg} / \mathrm{kg}$ diet fed-1) for 2 months. The $3^{\text {rd }}$ and $4^{\text {th }}$ groups was vaccinated using Aeromonas hydrophila bacterin, at the first day of experiment, but fish of $4^{\text {th }}$ group was fed on diet containing same dose of levamisole throughout the 2 months of experiment. At $1^{\text {st }}, 3^{\text {rd }}$ and $5^{\text {th }}$ week, blood samples were collected from all groups for hematological, immunological and serum biochemistry studies while fish of $2^{\text {nd }}$ group were subjected to histopathology. Challenge was done to all groups, at thirty day of experiment, through immersion of fish in virulent Aeromonas hydrophila (1g bacterial cells/liter) for 10min, the mortalities recorded and the dead fish used for the bacterial re-isolation. Catfish of $1^{\text {st }}$ group showed normal values throughout the period of the experiment. Fish of $2^{\text {nd }}$ group showed activation of melanomacrophages. Hyperplasia of hematopoietic tissue was evident at $3^{\text {rd }}-4^{\text {th }}$ week. Degenerative changes were mild at $1^{\text {st }}-2^{\text {nd }}$ week and become prominent at $5^{\text {th }}$ week. Fish of $3^{\text {rd }}$ group showed a significant gradual increase of leucocytes, phgocytosis, antibody titer, total protein and globulin, at $1^{\text {st }}-5^{\text {th }}$ week post-vaccination. Fish of $4^{\text {th }}$ group showed higher hematological and immunological values than those of $3^{\text {rd }}$ group. The relative level of protection after the challenge infection was 30,85 and $90 \%$ for the $2^{\text {nd }}, 3^{\text {rd }}$ and $4^{\text {th }}$ groups; respectively. The histopathological finding of this experiment showed the safety of the selected dose of levamesol on catfish. The other findings indicate its efficiency as immunostimulant in improving the immune response of catfish to Aeromonas hydrophila vaccine.
\end{abstract}

Key Words: Levamisole, Catfish (Clarias gariepenus), Aeromonas hydrophila.

Received: 17 June 2011

Accepted: 29 July 2011

Correspondence:

Salah Eldin Mesalhy Aly

The WorldFish Center, Abbassa, Sharkia, 44662, Egypt

E-mail: s.mesalhy@cgiar.org, salahaly@hotmail.com

Copyright : All rights reserved to Mediterranean Aquaculture and Environment Society (MAES) 


\section{Introduction}

Fish culture is an important industry where the production of fish worldwide increases every year. Disease outbreaks are encountered in the rapidly developing aquaculture industry and affecting the economic development of this sector (Yunxia, et al. 2001). Various chemotherapeutics have been used to treat bacterial infections in cultured fish for the last 20 years. However, the incidence of drugresistant bacteria has become a major problem in fish culture (Aoki, 1992). Vaccination is a useful prophylaxis for infectious diseases of fish but the development of vaccine against intracellular pathogens has not so far been successful. Therefore, the immediate control of all fish diseases using only vaccines is impossible (Sakai, 1999). The most effective method, in our opinion, may be the development of natural disease resistance in fish, where, the use of immunostimulants may be an effective mean of increasing the immune competency and disease resistance of fish.

Levamisole hydrochloride corrects the immunologic imbalance by modifying activities of T- lymphocytes and phagocytes. It stimulates cell- mediated immune reactivity by potentiate the rate of $\mathrm{T}$ - lymphocytes differentiation, responsiveness to antigens and mitogens, and activity of effectors lymphocytes (Booth and McDonald, 1982).

The present work was designed to study the effect of Levamisole on the health status and immune response of catfish (Clarias gariepenus) through vaccine administration together with histopathological and clinicopathological investigations.

\section{Materials and Methods}

Two hundred catfish (Clarias gariepenus), each of $150+15 \mathrm{~g}$ body weight, were divided into 4 equal groups (each of 50 fish and 5 replicates). Fish reared equally in a 20 glass aquaria
$(50 \times 60 \times 70 \mathrm{~cm}$ each) with water temperature maintained at $22+2^{\circ} \mathrm{C}$ and the fish fed on a basal diet of $25 \%$ protein along the period of experiment. Water was partially renewed daily and monitored for water quality weekly. The $1^{\text {st }}$ group served as a control. Fish of the $2^{\text {nd }}$ group was incorporating levamisole $(150 \mathrm{mg} / \mathrm{kg}$ diet fed $\left.^{-1}\right)$ for 2 months. The $3^{\text {rd }}$ and $4^{\text {th }}$ groups was vaccinated at the first day of experiment, but fish of $4^{\text {th }}$ group were fed on diet containing same dose of Levamisole throughout the 2 months of experiment. Vaccination of fish in $3^{\text {rd }}$ and $4^{\text {th }}$ groups was carried out using Aeromonas hydrophila bacterin, in a dose of $0.1 \mathrm{ml}$ formalinkilled bacterial cells/fish, via intraperitoneally (I/P) route.

Levamisole Hydrochloride: (Sigma chemical company) is a synthetic imidazothiazole derivative. It is the L-isomer of Dl-tetramisole. The Aeromonas hydrophila was supplied kindly from The WorldFish Center, Egypt while E. coli kindly supplied from the Department of Microbiology, Animal Health Research Institute, Dokki, Giza, Egypt and used for the evaluation of phagocytic $\%$.

Vaccine prepared by cultivation of Aeromonas hydrophila strain in Trypticase soya broth (TSB) that incubated at $35^{\circ} \mathrm{C}$ for 48 hours. The bacterial cultures were inactivated by the addition of formalin to give a final concentration of $0.3 \%$ and were held at room temperature overnight. The broth culture was centrifuged at $6000 \mathrm{rpm}$ for $15 \mathrm{~min}$ and washed three times with sterile saline solution. The preparation was held at $4^{\circ} \mathrm{C}$ until used. Safety test was performed according to Cardella and Eimers (1990). The safety test was performed by the intra-peritoneal (I/P) inoculation of 20 susceptible catfish with bacterin. The fish were kept under observation for 2 weeks postinjection. Sterility test was done by cultivation of the prepared vaccine on Rimler-Shotts agar and Trypticase soya agar and then incubated at 
$37^{\circ} \mathrm{C}$ for $24 \mathrm{hrs}$. The cultures were examined for bacterial growth.

The following values were estimated, at the end of $1^{\text {st }}, 3^{\text {rd }}$ and $5^{\text {th }}$ week, in the blood and serum of experimented fish; total red and white blood cells (Natt and Herrick, 1952 and Miller and Seward, 1971), blood hemoglobin (Drabkin, 1948), packed cell volume (Wintrobe, 1967), blood indices (Latimer, et al. 2003), the percentage and absolute values for different leukocytic cells (Jain, 1986), specific antibody titers (Baba, et al. 1993), phagocytosis (Torky and Diallo, 1983 and Leiboled, 1981), fractionation of serum proteins (Karcher and Landers, 2006), serum total proteins (Weichselbaum, 1946), serum level of aspertate aminotransferase (AST) and alanine aminotransferase ALT (Bergmeyer, et al. 1986), serum creatinine (Bartels, 1972), serum uric acid (Caraway, 1963). Also, tissue specimens were collected from fish of group 3 and histopathological technique was done according to Drury and Wallington (1980) to evaluate the safety of the used levamisole dose.

Based on the recorded immune parameters of the first experiment where best response was seen 1 month of levamisole application, same experiment repeated one more time using same number of catfish and artificial infection of all groups was done at thirty days of the experiment by immersion of 20 catfish from each group in diluted $24 \mathrm{hrs}$ broth culture of virulent Aeromonas hydrophila (1:5 in 0.5\% sodium chloride solution to give $1 \mathrm{~g}$ bacterial cells/liter) for $10 \mathrm{~min}$. The challenged fish were kept under observation for 4 weeks and the dead ones were used for Aeromonas hydrophila reisolation, meantime and the relative level of protection (RLP) among the challenged fish was estimated (Newman and Majnarich, 1982).

$\mathrm{RLP}=100$-percent of immunized mortality $\div$ percent of control mortalityx 100 .
This was performed using a one way and two way analysis of variance (ANOVA). Duncan's Multiple Range Test (Latimer, 2003) was used to determine differences among treatments (mean at significance level of $P<0.05$ ). Standard errors were also estimated. Analysis was carried out using the SAS package (SAS, 1996).

\section{Results}

The experimented catfish showed no significant in the total erythrocytic count and other erythrocytic parameters between different groups (Table 1). The total leukoncytic count was non significantly increased in levamisol group and significantly increased in both vaccinated and levamisol vaccinated groups, the increase was referred to the increase in lymphocytes (Table 2). A significant increase in the total protein and globulin was noticed in the vaccinated and levamisol vaccinated groups, the increase was varied with the period of experiment (Table 3). A significant increase in the AST, ALT, urea and creatinine was seen during some times of experiment in the levamisol vaccinated group (Table 4). The antibody titers was significantly increased in vaccinated and levamisol vaccinated groups while the phagocytic \% was significantly increased in the levamisol vaccinated group, the degree of significance was varied with the time of experiment (Table 5).

The histopathological studies, in the group treated with levamisole, revealed activation of melanomacrophages and hyperplasia of hematopoietic tissue and tubular nephrosis mainly vacuolar degeneration in the kidney. The liver showed congestion and marked activation of melanomacrophages. Some of the hepatic cells exhibited pyknotic nuclei. Spleen showed activation of melanomacrophages centers and proliferation of lymphocytes within the lymphoid follicles (Figure 1-4). 
Aly et al.

Table 1: Erythrocytic values in experimented catfish groups (mean \pm S.E):

\begin{tabular}{|c|c|c|c|c|c|c|c|}
\hline Group & $\begin{array}{l}\text { Period } \\
\text { (week) }\end{array}$ & $\begin{array}{c}\text { RBC } \\
\left(10^{6} / \mu \mathrm{L}\right)\end{array}$ & $\begin{array}{c}\mathrm{Hb} \\
(\mathrm{g} / \mathrm{dL})\end{array}$ & $\begin{array}{l}\text { PCV } \\
(\%)\end{array}$ & $\begin{array}{c}\text { MCV } \\
\text { (fL) }\end{array}$ & $\begin{array}{c}\text { MCH } \\
(\mathrm{Pg})\end{array}$ & $\begin{array}{c}\text { МCHC } \\
(\%)\end{array}$ \\
\hline \multirow{3}{*}{ 1- Control } & $1^{\text {st }}$ & $2.562 \pm 0.025$ & $9.825 \pm 0.035$ & $28.850 \pm 0.050$ & $112.47 \pm 3.40$ & $38.304 \pm 2.1$ & $34.055 \pm 0.21$ \\
\hline & $3^{\text {rd }}$ & $2.505 \pm 0.036$ & $9.685 \pm 0.015$ & $28.250 \pm 0.018$ & $112.77 \pm 1.5$ & $38.66 \pm 0.97$ & $34.28 \pm 0.52$ \\
\hline & $5^{\text {th }}$ & $2.805 \pm 0.018$ & $10.205+0.015$ & $29.07 \pm 0.035$ & $103.63 \pm 2.11$ & $36.38 \pm 0.41$ & $35.10 \pm 0.75$ \\
\hline \multirow{3}{*}{ 2- Levamisole } & $1^{\mathrm{st}}$ & $2.621 \pm 0.26$ & $9.895 \pm 0.31$ & $28.980 \pm 0.43$ & $110.56 \pm 1.24$ & $37.75 \pm 0.39$ & $34.14 \pm 0.14$ \\
\hline & $3^{\text {rd }}$ & $2.485 \pm 0.26$ & $9.630 \pm 0.34$ & $28.326 \pm 0.46$ & $113.987 \pm 1.3$ & $38.75 \pm 0.41$ & $33.40 \pm 0.51$ \\
\hline & $5^{\text {th }}$ & $2.840 \pm 0.31$ & $10.190 \pm 0.29$ & $28.99 \pm 0.48$ & $102.08 \pm 1.2$ & $35.88 \pm 0.52$ & $35.15 \pm 0.64$ \\
\hline \multirow{3}{*}{ 3-Vaccinated } & $1^{\text {st }}$ & $2.502 \pm 0.16$ & $9.585 \pm 0.48$ & $27.45 \pm 0.72$ & $112.77 \pm 5.3$ & $38.204 \pm 3.2$ & $34.755 \pm 0.21$ \\
\hline & $3^{\text {rd }}$ & $2.595 \pm 0.15$ & $9.745 \pm 0.39$ & $29.55 \pm 0.46$ & $113.97 \pm 2.8$ & $37.46 \pm 1.2$ & $33.68 \pm 0.26$ \\
\hline & $5^{\text {th }}$ & $3.005 \pm 0.33$ & $10.475 \pm 0.01$ & $30.87 \pm 0.17$ & $102.04 \pm 1.4$ & $34.38 \pm 0.16$ & $34.255 \pm 0.31$ \\
\hline \multirow{3}{*}{$\begin{array}{l}\text { 4- Levamisole and } \\
\text { Vaccinated }\end{array}$} & $1^{\text {st }}$ & $2.567 \pm 0.46$ & $9.672 \pm 0.81$ & $27.632 \pm 0.51$ & $107.64 \pm 2.10$ & $37.67 \pm 0.37$ & $35.00 \pm 0.43$ \\
\hline & $3^{\text {rd }}$ & $2.625 \pm 0.17$ & $9.764 \pm 0.38$ & $29.380 \pm 0.16$ & $111.92 \pm 1.2$ & $37.19 \pm 0.93$ & $33.23 \pm 0.49$ \\
\hline & $5^{\text {th }}$ & $3.059 \pm 0.28$ & $10.450 \pm 0.34$ & $30.52 \pm 0.27$ & $99.77 \pm 1.1$ & $34.16 \pm 0.69$ & $34.23 \pm 0.48$ \\
\hline
\end{tabular}

Table 2: Total and differential leukocytic count in experimented catfish groups (mean \pm S.E):

\begin{tabular}{|c|c|c|c|c|c|c|c|}
\hline Group & $\begin{array}{l}\text { Period } \\
\text { (week) }\end{array}$ & $\begin{array}{c}\text { T.L.C. } \\
\left(10^{3} / \mu \mathbf{L}\right)\end{array}$ & $\begin{array}{l}\text { Neutro. } \\
\left(10^{3} / \mu \mathbf{L}\right)\end{array}$ & $\begin{array}{l}\text { Lymph. } \\
\left(10^{3} / \mu \mathrm{L}\right)\end{array}$ & $\begin{array}{l}\text { Monocy. } \\
\left(10^{3} / \mu \mathrm{L}\right)\end{array}$ & $\begin{array}{c}\text { Eosinoph. } \\
\left(10^{3} / \mu \mathrm{L}\right)\end{array}$ & $\begin{array}{l}\text { Basoph. } \\
\left(10^{3} / \mu \mathbf{L}\right)\end{array}$ \\
\hline \multirow{3}{*}{ 1- Control } & $1^{\mathrm{st}}$ & $24.05 \pm 0.050$ & $8.041 \pm 0.017$ & $14.241 \pm .026$ & $0.552 \pm 0.002$ & $1.116 \pm 0.005$ & $0.101 \pm 0.005$ \\
\hline & $3^{\text {rd }}$ & $25.75 \pm 0.023$ & $9.541 \pm 0.018$ & $14.421 \pm 0.050$ & $0.582 \pm 0.001$ & $1.156 \pm 0.003$ & $0.111 \pm 0.004$ \\
\hline & $5^{\text {th }}$ & $26.05 \pm 0.10$ & $9.741 \pm 0.28$ & $13.871 \pm 0.13$ & $0.982 \pm 0.17$ & $1.346 \pm 0.21$ & $0.111 \pm 0.02$ \\
\hline \multirow{3}{*}{ 2- Levamisole } & $1^{\text {st }}$ & $25.027 \pm 0.024$ & $8.334 \pm 0.016$ & $14.962 \pm 0.037$ & $0.438 \pm 0.002$ & $1.192 \pm 0.002$ & $0.101 \pm 0.001$ \\
\hline & $3^{\text {rd }}$ & $27.751 \pm 0.13$ & $10.067 \pm 0.026$ & $15.524 \pm 0.11$ & $0.528 \pm 0.002$ & $1.352 \pm 0.005$ & $0.104 \pm 0.002$ \\
\hline & $5^{\text {th }}$ & $26.215 \pm 0.21$ & $10.162 \pm 0.37$ & $13.690 \pm 0.29$ & $0.960 \pm 0.15$ & $1.295 \pm 0.11$ & $0.108 \pm 0.02$ \\
\hline \multirow{3}{*}{ 3- Vaccinated } & $1^{\text {st }}$ & $32.27 \pm 0.038 *$ & $10.501 \pm 0.025$ & $20.041 \pm 0.017^{*}$ & $0.472 \pm 0.006$ & $1.056 \pm 0.002$ & $0.101 \pm 0.003$ \\
\hline & $3^{\text {rd }}$ & $31.18 \pm 0.019 *$ & $10.501 \pm 0.031$ & $18.731 \pm 0.036^{*}$ & $0.642 \pm 0.006^{*}$ & $1.156 \pm 0.001$ & $0.111 \pm 0.002$ \\
\hline & $5^{\text {th }}$ & $29.641 \pm 0.23 *$ & $9.701 \pm 0.40$ & $17.751 \pm 0.11 *$ & $0.902 \pm 0.26$ & $1.176 \pm 0.19$ & $0.111 \pm 0.03$ \\
\hline \multirow{3}{*}{$\begin{array}{l}\text { 4- Levamisole } \\
\text { and Vaccinated }\end{array}$} & $1^{\mathrm{st}}$ & $36.58 \pm 0.12 *$ & $11.034 \pm 0.019$ & $22.368 \pm 0.11 *$ & $0.418 \pm 0.027$ & $1.659 \pm 0.001$ & $0.101 \pm 0.002$ \\
\hline & $3^{\text {rd }}$ & $37.12 \pm 0.024 * *$ & $10.130 \pm 0.021$ & $24.852 \pm 0.038 * *$ & $0.823 \pm 0.002 *$ & $1.214 \pm 0.004$ & $0.101 \pm 0.001$ \\
\hline & $5^{\text {th }}$ & $32.451 \pm 0.42 *$ & $10.117 \pm 0.21$ & $19.810 \pm 0.29 *$ & $1.251 \pm 0.15$ & $1.172 \pm 0.03$ & $0.101 \pm 0.02$ \\
\hline
\end{tabular}

* Significant at $\mathrm{P}<0.05, * *$ Highly Significant at $\mathrm{P}<0.01$.

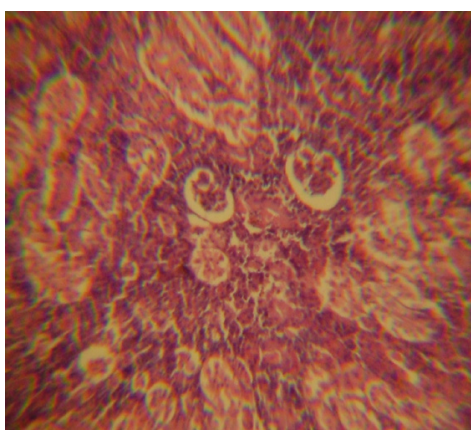

Fig. 1: Kidney, of catfish treated with levamisole, showing hyperplasia of hematopoietic tissue. $\mathrm{H}$ and $\mathrm{E}$ stain, $\mathrm{x} 250$.

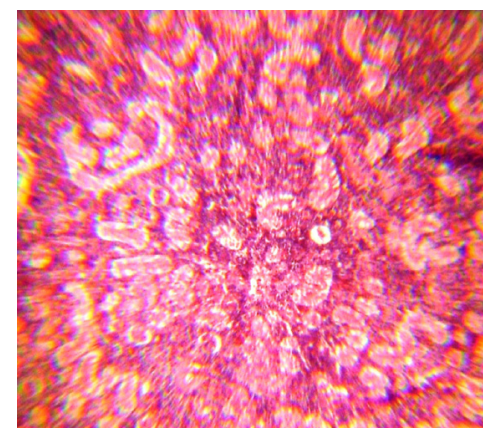

Fig. 2: Kidney, of catfish treated with levamisole, showing tubular nephrosis mainly vacuolar degeneration in the kidney. $\mathrm{H}$ and $\mathrm{E}$ stain, $\mathrm{x} 100$. 
Table 3: Proteinogram in experimented catfish groups (mean \pm S.E):

\begin{tabular}{|c|c|c|c|c|c|c|c|c|}
\hline Group & $\begin{array}{l}\text { Period } \\
\text { (week) }\end{array}$ & $\begin{array}{c}\text { T.P. } \\
(\mathrm{gm} / \mathrm{dl})\end{array}$ & $\begin{array}{l}\text { Albu. } \\
\text { (gm/dl) }\end{array}$ & $\begin{array}{c}\text { Glob. } \\
\text { (gm/dl) }\end{array}$ & A/G Ratio & $\alpha$ & $\beta$ & $\delta$ \\
\hline \multirow{3}{*}{ 1- Control } & $1^{\text {st }}$ & $5.980 \pm 0.010$ & $2.54 \pm 0.01$ & $3.44 \pm 0.011$ & $0.738 \pm 0.05$ & $1.4 \pm 0.02$ & $1.3 \pm 0.01$ & $0.7 \pm 0.02$ \\
\hline & $3^{\text {rd }}$ & $6.14 \pm 0.12$ & $2.75 \pm 0.12$ & $3.39 \pm 0.10$ & $0.811 \pm 0.09$ & $1.4 \pm 0.02$ & $1.29 \pm 0.01$ & $0.7 \pm 0.02$ \\
\hline & $5^{\text {th }}$ & $6.38 \pm 0.11$ & $2.84 \pm 0.12$ & $3.54 \pm 0.11$ & $0.802 \pm 0.35$ & $1.4 \pm 0.01$ & $1.39 \pm 0.01$ & $0.75 \pm 0.02$ \\
\hline \multirow{3}{*}{ 2- Levamisole } & $1^{\text {st }}$ & $6.24 \pm 0.028$ & $2.54 \pm 0.31$ & $3.70 \pm 0.27$ & $0.686 \pm 0.15$ & $1.5 \pm 0.01$ & $1.45 \pm 0.01$ & $0.75 \pm 0.02$ \\
\hline & $3^{\text {rd }}$ & $7.43 \pm 0.21$ & $2.74 \pm 0.16$ & $4.69 \pm 0.13$ & $0.584 \pm 0.18$ & $1.84 \pm 0.01 *$ & $1.65 \pm 0.02$ & $1.2 \pm 0.01 *$ \\
\hline & $5^{\text {th }}$ & $6.56 \pm 0.13$ & $2.83 \pm 0.18$ & $3.73 \pm 0.11$ & $0.758 \pm 0.16$ & $1.41 \pm 0.02$ & $1.31 \pm 0.01$ & $1.1 \pm 0.01 *$ \\
\hline \multirow{3}{*}{ 3- Vaccinated } & $1^{\text {st }}$ & $7.35 \pm 0.07 *$ & $2.38 \pm 0.04$ & $4.97 \pm 0.05^{*}$ & $0.478 \pm 0.18$ & $2.1 \pm 0.02 *$ & $1.9 \pm 0.02$ & $0.97 \pm 0.01 *$ \\
\hline & $3^{\text {rd }}$ & $7.44 \pm 0.15^{*}$ & $2.71 \pm 0.09$ & $4.73 \pm 0.13$ & $0.572 \pm 0.05$ & $1.8 \pm 0.02 *$ & $1.53 \pm 0.01$ & $1.4 \pm 0.01 *$ \\
\hline & $5^{\text {th }}$ & $7.13 \pm 0.09$ & $2.75 \pm 0.21$ & $4.38 \pm 0.18$ & $0.627 \pm 0.15$ & $1.74 \pm 0.03 *$ & $1.39 \pm 0.03$ & $1.25 \pm 0.02 *$ \\
\hline \multirow{3}{*}{$\begin{array}{l}\text { 4- Levamisole } \\
\text { and Vaccinated }\end{array}$} & $1^{\mathrm{st}}$ & $7.41 \pm .16^{*}$ & $2.58 \pm 0.27$ & $4.830 \pm 0.38 *$ & $0.528 \pm 0.13$ & $1.8 \pm 0.02$ & $1.77 \pm 0.01$ & $1.26 \pm 0.01 *$ \\
\hline & $3^{\text {rd }}$ & $8.63 \pm 0.26^{* *}$ & $2.76 \pm 0.29$ & $5.87 \pm 0.34^{* *}$ & $0.470 \pm 0.24$ & $2.50 \pm 0.02$ & $1.77 \pm 0.01 *$ & $1.60 \pm 0.02 * *$ \\
\hline & $5^{\text {th }}$ & $7.50 \pm 0.29 *$ & $2.73 \pm 0.20$ & $4.77 \pm 0.37 *$ & $0.572 \pm 0.32$ & $* *$ & $1.68 \pm 0.01$ & $1.28 \pm 0.02 *$ \\
\hline
\end{tabular}

* Significant at $\mathrm{P}<0.05, * *$ Highly Significant at $\mathrm{P}<0.01$

Table 4: Liver enzymes and renal function in experimented catfish along the period of study (mean \pm S.E):

\begin{tabular}{lcccccc}
\hline \multicolumn{1}{c}{ Group } & $\begin{array}{c}\text { Period } \\
(\mathbf{w e e k})\end{array}$ & $\begin{array}{c}\text { AST } \\
(\mathbf{u} / \mathbf{L})\end{array}$ & $\begin{array}{c}\text { ALT } \\
(\mathbf{u} / \mathbf{L})\end{array}$ & $\begin{array}{c}\text { Uric acid } \\
(\mathbf{m g} / \mathbf{d l})\end{array}$ & $\begin{array}{c}\text { Urea } \\
(\mathbf{m g} / \mathbf{d l})\end{array}$ & $\begin{array}{c}\text { Creatinine } \\
(\mathbf{m g} / \mathbf{d l})\end{array}$ \\
\hline \multirow{3}{*}{ 1- Control } & $1^{\text {st }}$ & $21.40 \pm 0.30$ & $19.950 \pm 0.05$ & $2.02 \pm 0.14$ & $3.20 \pm 0.017$ & $0.55 \pm 0.07$ \\
& $3^{\text {rd }}$ & $23.41 \pm 0.24$ & $17.83 \pm 0.38$ & $2.18 \pm 0.06$ & $3.20 \pm 0.02$ & $0.54 \pm 0.03$ \\
& $5^{\text {th }}$ & $24.30 \pm 029$ & $18.37 \pm 0.42$ & $2.20 \pm 0.11$ & $3.19 \pm 0.01$ & $0.55 \pm 0.03$ \\
\hline \multirow{3}{*}{ 2- Levamisole } & $1^{\text {st }}$ & $24.11 \pm 0.28$ & $22.43 \pm 0.31$ & $2.05 \pm 0.03$ & $3.63 \pm 0.01$ & $0.58 \pm 0.05$ \\
& $3^{\text {rd }}$ & $24.09 \pm 0.21$ & $18.40 \pm 0.31$ & $2.19 \pm 0.10$ & $3.24 \pm 0.04$ & $0.56 \pm 0.03$ \\
& $5^{\text {th }}$ & $24.72 \pm 0.31$ & $19.89 \pm 0.41$ & $2.31 \pm 0.17$ & $3.22 \pm 0.01$ & $0.56 \pm 0.10$ \\
\hline \multirow{3}{*}{ 3- Vaccinated } & $1^{\text {st }}$ & $29.50 \pm 0.12 *$ & $25.63 \pm 0.16^{*}$ & $2.08 \pm 0.09$ & $3.42 \pm 0.04$ & $0.56 \pm 0.01$ \\
& $3^{\text {rd }}$ & $27.31 \pm 0.25 *$ & $19.47 \pm 0.29$ & $2.29 \pm 0.09$ & $3.26 \pm 0.05$ & $0.56 \pm 0.03$ \\
& $5^{\text {th }}$ & $25.61 \pm 0.37$ & $19.81 \pm 0.17$ & $2.29 \pm 0.24$ & $3.23 \pm 0.01$ & $0.57 \pm 0.03$ \\
\hline \multirow{3}{*}{ 4- Levamisole and } & $1^{\text {st }}$ & $31.18 \pm 0.25 *$ & $26.13+0.34 *$ & $2.17 \pm 0.04$ & $4.27 \pm 0.02 *$ & $0.59 \pm 0.03$ \\
Vaccinated & $3^{\text {rd }}$ & $26.23 \pm 0.26 *$ & $19.34 \pm 0.24$ & $2.31 \pm 0.9$ & $4.26 \pm 0.01$ & $0.58 \pm 0.02 *$ \\
& $5^{\text {th }}$ & $26.49 \pm 0.13$ & $20.07 \pm 0.25$ & $2.33 \pm 0.22$ & $3.23 \pm 0.03$ & $0.57 \pm 0.04$ \\
\hline
\end{tabular}

* Significant at $\mathrm{P}<0.05, * *$ Highly Significant at $\mathrm{P}<0.01$.

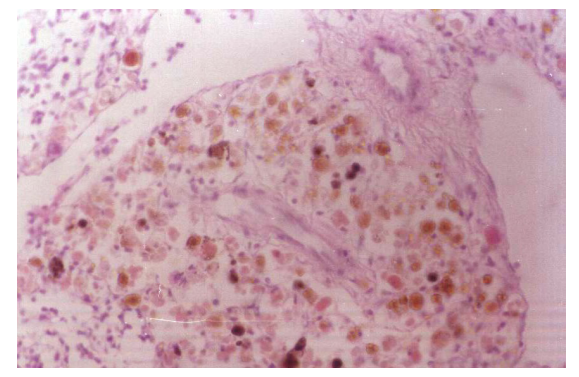

Fig. 3: Liver, of catfish treated with levamisole, showing congestion and marked activation of melanomacrophages. $\mathrm{H}$ and $\mathrm{E}$ stain, x100.

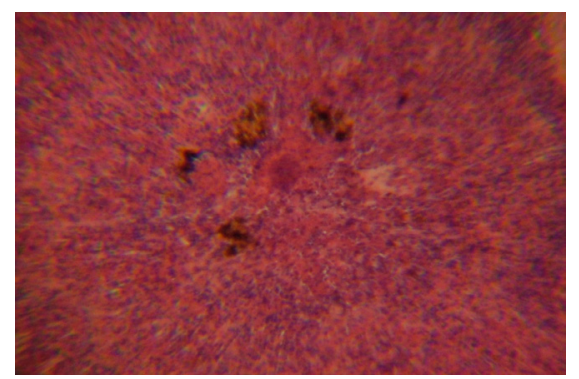

Fig. 4: Spleen, of catfish treated with levamisole, showing activation of melanomacrophages centers and proliferation of lymphocytes. $\mathrm{H}$ and $\mathrm{E}$ stain, $\mathrm{x} 100$. 
Table 5: Antibody titer and phagocytic percentage in experimented catfish along the period of study (mean \pm S.E):

\begin{tabular}{cccc}
\hline Group & $\begin{array}{c}\text { Period } \\
\text { (week) }\end{array}$ & $\begin{array}{c}\text { Antibody } \\
\text { titers }\end{array}$ & $\begin{array}{c}\text { Phagocytic } \\
\%\end{array}$ \\
\hline \multirow{3}{*}{ 1- Control } & $1^{\text {st }}$ & $2.00 \pm 0.02$ & $40.41 \pm 0.93$ \\
& $3^{\text {rd }}$ & $2.00 \pm 0.02$ & $41.97 \pm 1.07$ \\
& $5^{\text {th }}$ & $2.00 \pm 0.02$ & $40.27 \pm 0.92$ \\
\hline \multirow{2}{*}{ 2- Levamisole } & $1^{\text {st }}$ & $2.01 \pm 0.02$ & $41.17 \pm 1.16$ \\
& $3^{\text {rd }}$ & $2.39 \pm 0.04$ & $49.19 \pm 1.14$ \\
& $5^{\text {th }}$ & $2.95 \pm 0.01$ & $42.56 \pm 0.92$ \\
\hline \multirow{3}{*}{ 3- Vaccinated } & $1^{\text {st }}$ & $3.11 \pm 0.04$ & $44.20 \pm 0.66$ \\
& $3^{\text {rd }}$ & $8.13 \pm 0.03 * *$ & $47.42 \pm 1.03$ \\
& $5^{\text {th }}$ & $6.72 \pm 0.06 *$ & $40.27 \pm 0.92$ \\
\hline \multirow{2}{*}{ 4- Levamisole } & $1^{\text {st }}$ & $3.21 \pm 0.21$ & $51.69 \pm 1.07$ \\
and Vaccinated & $3^{\text {rd }}$ & $8.94 \pm 0.03 *$ & $72.57 \pm 1.08 * *$ \\
& $5^{\text {th }}$ & $6.83 \pm 0.04 *$ & $63.25 \pm 1.04 *$ \\
\hline
\end{tabular}

* Significant at $\mathrm{P}<0.05, * *$ Highly Significant at $\mathrm{P}<0.01$.

\section{Discussion}

Levamisole hydrochloride is a water soluble antinematodal drug of broad spectrum activity in various animal species (Jones, et al. 1977). Recently Schmahl and Taraschewski (1987) reported that, levamisole is effective in treating fish parasitized by monogenea. One year later, Taraschewski et al. (1988) stated that, levamisole is a highly potent drug treating Anguillicola crassus of eels. Also Hartman (1989) and Fontaine et al. (1990) reported that, levamisole cleared the parasite (Anguillicola crassus) from swim bladder of eel.

Levamisole modulates the immune system and it has the greatest benefit in the immunologically depressed animal (Booth and McDonald, 1982). Levamisole, in the current study, induced no significant changes in the eryhtrocytic values that may show the safety of levamisole but a significant increase on the total leucocytic count in vaccinated fish was seen (Tables 1,2 ). The increase in the total leukocytic count could be due to the stimulating effect of levamisole.

In our results, the addition of levamisole to the diet of catfish at small doses $150 \mathrm{mg} / \mathrm{kg}$ of diet stimulated the humoral immune response against Aeromonas hydrophila bacterin, the increase was significant at the first week and highly significant at the third week of experiment (Table 3). These results are parallel to those reported by Siwicki et al. (1990) who recognized enhancement of specific immune response of rainbow trout indicated by significant increase of the plaque forming cells after injection of Yersinia ruckeri O-antigen in combination with small dose of levamisole $(10 \mu \mathrm{g} / \mathrm{ml})$. Also in a parallel studies, the application of levamisole to carp diet in small doses enhanced the phagocytic activity in neutrophils and their myeloperoxidase activity, increase the leucocytes number and serum lysozyme levels. (Siwicki, 1987, 1989). The immune stimulation of levamisole at small doses may be attributed to the activation of the non-specific immune response particularly macrophages (Fischer, et al. 1975), this activation could enhance the antigen trapping and processing.

The present investigation dealt with the study of the effects of levamisole on fresh water fish as immunostimulant. Among the adverse effects of levamisole HCL are those reported in this work on some liver and kidney function tests as well as on histopathological examination. Levamisole HCL induced a non-significant increase in serum Alanine transaminase enzyme (S.ALT) and Aspartate aminotransferase (S.AST) of catfish treated with levamisole $(150 \mathrm{mg} / \mathrm{kg}$ diet $)$ during the experiment (Table 4). These findings are supported by the reported histopathological alterations of the hepatic tissue. These alterations included perivascular aggregation of lympho cytes and hydropic degeneration of the hepatocytes. These findings are confirmed by the findings reported by Gammaz et al. (1993). El-Bouhi and El-Qelsh (1993) observed aggregation of melanomacrophages in the hepatoportal area and hydropic degeneration in the liver of Tilapia nilotica treated with levamisole as a medical bath. Our results revealed that, levamisole induced also a nonsignificant increase in the serum levels of urea, uric acid and creatinine (Table 4). These 
findings indicated that the urea, uric acid and creatinine clearance were decreased, the later was found to be due to the renal impairment (Benjamin, 1961). The increased plasma urea in this study was in accordance with Kaneko (1980) who mentioned that, increased urea production can occur in a variety of conditions such as renal shutdown resulting in insufficient urea excretion. A hypothesis which appears to be accepted in our case since the kidney suffered from some degenerative changes as mentioned before. This suggestion was supported by the reported histopathological changes in this work on the kidney of catfish exposed to levamisole where tubular nephrosis was evident.

Levamisole induced non-significant to significant increase on the antibody titer (Table 5). This agreed with the findings expressed by Zhang et al. (1999) who noticed that levamisole enhanced B-lymphocyte differentiation, and supported by Sun et al. (2003), they suggested that levamisole may modulate serum interleukin-6 (IL-6) level which is according to Sheehan, (1997), that secreted by $\mathrm{TH}_{2}$ (T-helper-2) and can promote B-cell activation, proliferation and differentiation into antibody producing plasma cells.

El-Bouhi and El-Qelsh (1993) revealed that, a medical bath treatment of fish (Tilpia nilotica) with levamisole caused interstitial aggregation of round cells and moderate activation of melanomacrophages of kidneys. Also, levamisole, in the current study, induced non-significant increases in the phagocytosis percentage in levamisole treated groups and significant increase in the phagocytosis of vaccinated group to a level comparable with that of the corresponding control (Table 5). These results were confirmed by those obtained by Drews (1990) and Afifi (1990) in which they suggested that levamisole can enhance production and secretion of IL-2 (Interleukin-2) and interferon. According to Sheehan (1997), IL-2 and interferon-gamma are secreted by TH1 (T-helper-1) and function to promote activation of Tc (T-cytotoxic) cells, NK (Natural
Killer) cells and macrophage, and consequently phagocytic activity.

The histopathological findings, in the group treated with levamisole revealed activation of melanomacrophages and immune tissue in different organs. Mild degenerative changes were seen in the liver and kidneys mainly vacuolar degeneration. The histopathological pictures were supporting the recorded hematological and immunological values and showed the safety of the selected dose of levamisole. These results were on line with that obtained with El-Bouhi and El-Qelsh (1993).

The challenge with Aeromonas hydrophila resulted a 85, 30 and $80 \%$ relative level of protection in groups 2, 3 and 4 respectively, these results nearly similar with Baba et al. (1993), they reported that carp immersed in a levamisole bath $(10 \mathrm{mg} / \mathrm{ml}, 24 \mathrm{~h})$ showed enhanced resistance against Aeromonas hydrophila and its phagocytes increased chemotactic ability, phagocytic activity and chemiluminescence. The observation of Siwicki (1989) about the enhancing effect of levamisole on the non-specific immune response for 3 months is of great importance especially as a possible prophylactic measures. This observation was supported by the results obtained in the present study where catfish fed levamisole were protected against challenge with Aeromonas hydrophila. This protection was significant in catfish fed levamisole before challenge than those fed levamisole as therapy because the previously activation of phagocytic cells was more effective. Unfortunately, no available literature explained the therapeutic effect of levamisole aganist bacterial diseases.

It could be concluded that, levamisole may help to enhance the immune response of catfish to some vaccines and against infection.

\section{References}

Afifi, M.A. 1990. Studies on the role of some immunostimulants in using poultry vaccines. Ph.D., Faculty of Veterinary Medicine, Cairo University. 
Aoki, T. 1992. Chemotherapy and drug resistance in fish farms in Japan. in Diseases in Asian aquaculture I, fish health section, eds. M. Shariff, R.P. Subasinghe \& J.R. Arthur, Asian Fisheries Society, Manila, Philippines, pp. 519-529.

Baba, T., Watase, Y. \& Yoshinaga, Y. 1993. Activation of mononuclear phagocyte function by levamisole immersion in carp. Nippon Suisan Gakkaishi. 59, pp. 301-307.

Bartels, H., Bohmer, M. \& Heierli, C. 1972. Serum creatinine determination without protein precipitation. Clinica Chimica Acta. 37, pp. 193-197.

Benjamin, M.M. 1961. Outline of veterinary clinical pathology. 2nd ed. Iowa State University Press, Ames, Iowa.

Bergmeyer, H., Horder, M. \& Rej, J. 1986. Coloumetric determination of transaminases. Journal of Clinical Chemistry and Clinical Biochemistry. pp. 24-497.

Booth, N.H. \& McDonald, C.E. 1982. Veterinary pharmacology and therapeutics. 5th ed. Iowa State University Press, Ames, Iowa.

Caraway, W.T. 1963. Standard methods of clinical chemistry. Academic Press, New York.

Cardella, A. \& Eimers, M.E. 1990. Safety and potency testing of federally licensed fish bacterins. Journal of Aquatic Animal Health. 2, pp. 49-55.

Drabkin, D.L. 1948. The standardization of hemoglobin measurements. The American Journal of the Medical Sciences. 215, pp. 110-111.

Drews, J. 1990. Substances with an antiallergic effect, immunopharmacology - principles and perspectives. Springer-Verlag, Berlin, Heidelberg.

Drury, R.A.B. \& Wallington, E.A. 1980. Carleton's histological techniques. 5th ed. Oxford University Press, Oxford, New York, Toronto.

El-Bouhi, Z.M. \& El-Qelsh, M.E. 1993. Evaluation of the anthelmintic efficacy of levamisole and its side effects on Tilapia nilotica (Oreochromus niloticus). Zagazig Veterinary Journal. 21 (3), pp. 497-511.
Fischer, G.W., Podgore, J.K. \& Bass, J.W. 1975. Enhanced host defense mechanisms with levamisole in suckling rats. Journal of Infectious Diseases. 132 (5), pp. 578-581.

Fontaine, Y.A., Le Belle, N., Lopez, E., Querat, B., Vidal, B., Barthelemy, L., Sebert, P., Alinat, J. \& Petter, A.J. 1990. Infestation of French eel populations (Anguilla anguilla L.) by nematodes (Anguillicola crassus), therapeutic trials and evaluation of potential risks related to the ecophysiology of the host [Infestation de populations Francaises d'anguilles (Anguilla anguilla L.) par des nematodes (Anguillicola crassus): Essais therapeutiques evaluation de risques potentiels lies a l'ecophysiologie de l'hote]. Annales de Parasitologie Humaine et Comparee. 65 (2), pp. 64-68.

Gammaz, H.A., Abdella, O.A. \& El-Miniawy, H.M.F. 1993 Prelude to the adverse effects of levamisole and niclosamide used concemttently. Assiut Veterinary Medical Journal. 28 (56), pp. 176-185.

Hartman, F. 1989. Investigations on the effectiveness of levamisol as a medication against the eel parasite Anguillicola crassus (Nematoda). Disease of Aquatic Organisms. 7, pp. 185-190.

Jain, N.C. 1986. Schalm's veterinary hematology. 4th ed. Lea \& Febiger, Philadelphia.

Jones, L.M., Booth, N.H. \& McDonald, L.E. 1977. Veterinary pharmacology and therapeutics. 4th ed. Iowa State University Press, Ames, Iowa.

Kaneko, J.J. 1980. Clinical biochemistry of domestic animals. 3rd ed. Academic Press, New York.

Karcher, A. \& Landers, J.P. 2006. Electrophoresis. in Tietz textbook of clinical chemistry, eds. C.A. Burtis, E.R. Ashwood \& D.E. Bruns. 4th ed. Elsevier Saunders, pp. 121-140.

Latimer, K.S., Mahaffey, E.A. \& Prasse, K.W. 2003. Duncan and Prasse's veterinary laboratory medicine: Clinical pathology. 4th ed. Iowa State Press, Ames.

Leiboled, J. 1981. Cellular immdogic Eine pratishe Einfuhrung. Hannover vet. School, West Germany. 
Miller, J.P. \& Seward, A.k. 1971. Methods in clinical chemistry. St. Louis, Washington D. C., Toronto.

Natt, M.P. \& Herrick, C.A. 1952. A new blood diluent for counting the erythrocytes and leucocytes of the chicken. Poultry Science. 31, pp. 735-738.

Newman, S.G. \& Majnarich, J.J. 1982. Direct immersion vaccination of juvenile rainbow trout Salmo gairdneri Richardson and juvenile coho salmon Oncorhynchus kisutch (Walbaum), with a Yersinia ruckeri bacterin. Journal of Fish Disease. 5, pp. 339-341.

Sakai, M. 1999. Current research status of fish immunostimulants. Aquaculture. 172 (1-2), pp. 63-92.

SAS Institute 1996. Statistical analysis system: User's guide. SAS Institute, Cary, North Carolina, USA.

Schmahl, G. \& Taraschewski, H. 1987. Treatment of fish parasites - 2. Effects of praziquantel, niclosamide, levamisole$\mathrm{HCl}$ and metrifonate on monogenea (Gyrodactylus aculeati, Diplozoon paradoxum). Parasitology Research. 73 (4), pp. 341-351.

Sheehan, C. 1997. Clinical immunology: Principles and laboratory diagnosis. 2nd ed. Lippincott Williams \& Wilkins.

Siwicki, A.K. 1987. Immunomodulating activity of levamisole in carp spawners, Cyprinus carpio L. Journal of Fish Biology. 31 (Suppl. A), pp. 245-246.

Siwicki, A.K. 1989. Immunostimulating influence of levamisole on nonspecific immunity in carp (Cyprinus carpio). Developmental and Comparative Immunology. 13 (1), pp. 87-91.
Siwicki, A.K., Anderson, D.P. \& Dixon, O.W. 1990. In vitro immunostimulation of rainbow trout (Oncorhynchus mykiss) spleen cells with levamisole. Developmental and Comparative Immunology. 14 (2), pp. 231-237.

Sun, A., Chia, J.S., Chang, Y.F. \& Chiang, C.P. 2003. Levamisole and Chinese medicinal herbs can modulate the serum interleukin-6 level in patients with recurrent aphthous ulcerations. Journal of Oral Pathology and Medicine. 32 (4), pp. 206-214.

Taraschewski, H., Renner, C. \& Mehlhorn, H. 1988. Treatment of fish parasites. 3. Effects of levamisole $\mathrm{HCl}$, metrifonate, fenbendazole, mebendazole and ivermectin on Anguillicola crassus (nematodes) pathogenic in the air bladder of eels. Parasitology Research. 74 (3), pp. 281-289.

Torky, H.A. \& Diallo, B. 1983. Effect of immunization with thermostable enterotoxin of E-coli on phagocytosis and lethality. Zagazig Veterinary Journal. 7, pp. 357-371.

Weichselbaum, T.E. 1946. An accurate and rapid methode for determination of proteins in small amount of blood, serum and plasma. American Journal of Clinical Pathology. 16, pp. 40-48.

Wintrobe, M.M. 1967. Clinical haematology. Wintrobe, Lea and Febiger, Philadelphia.

Yunxia, Q., Jianzhong, S. \& Guoliang, W. 2001. A review of principal bacterial diseases of mari-culture fish. Transaction of Oceanology and Limnology. 2, pp. 78-87.

Zhang, R.J., Tong, J.M. \& Huang, Y. 1999. Effect of levamisole in diets on immune function in broiler chicks. Chinese Journal of Animal Science. 35 (5), pp. 5-8. 